\title{
日本総合診療医学会 国際フォーラム「あるべき病院総合医像を求めて」記録
}

\section{シンポジウム 1 認定制度はこう变わる}

\section{日本プライマリ・ケア連合学会による専門医，認定制度について}

\section{討 論 \\ 大滝 純司（司会）}

ではいまご発表いただいた内容と日本プライマリ・ケア連合学会の認定制度についてご討論をお願いし ます。本日は何かを決める会ではありません，情報を共有することが目的です。では皆様から自由にご意見， ご質問をいただきたいと思います。

フロアより (A)：自治医大卒業生や地域枠の医師たちは研修施設を選べません。プログラム認定だと研修 施設を選べないのですが，このような事情のある医師たちへの対策はありますか? 自治医大の卒業生は, 各県に帰って研修しますので，地域の中核病院が研修施設でないと学会のプログラムに入れません，対策 を望みます。

竹村：本当に貴重なご意見だと思います。自治医大の卒業生が進めるようなプログラムを提供したかった ので，そのようなご意見が今までなぜ聞かれなかったのかと思います。これは学会で早急に対策をとるべ きだと思います。ただプログラム認定であればひとつの研修施設で継続して研修をしなければならないと いうのではなく，研修場所を変えることは可能です。またひとりで離島やへき地に研修に行く場合も，イ ンターネットや何らかの手段で常に特定の医師とコミュニケーションがとれる，もしくは特定のある指導 医が定期的に指導に行くことによって診療所での家庭医療専門医の研修と認めるとなっています。

山城：今の質問は富山県でも出ています。若い人にも専門医がとれるような制度設計が必要で，今動き始 めたところです。

伊藤：プライマリ・ケア学会では，プログラムに固定しないで多くの施設で研修をしてきた人が受験でき る形にしていました，プログラムとして認定されていないところの医師が受験できないとはしていません. 今後意に反したところで働かなくてはならない人たちを救うような，プログラムだけではない対策を立て る必要があると思います。

A : 地域によって温度差がありますので，学会のほうからも何らかの支援をお願いします。

$\mathbf{C}:$ 年間 3,4 人の初期研修医を受け入れています。半分くらい当院に残るのですが, 彼らは将来臟器別のス ペシャリストになりたいのか，家庭医になりたいのかまだはっきりしないまま，もう少し病院の中で総合 的な仕事をしたいというニーズで残ります．3 年目からのホスピタリストの研修プログラムを確立してほ しいと思います。現在の家庭医専門医を取得したあとにホスピタリストというのでは，われわれのところ の研修医は残らないと思いますので検討をお願いします。

石丸：プライマリ・ケア医の専門性を確立してそのキャリアパスを示すことも重要ですので，まず今の研 修ルートを確立しょうというのが現状だと思います。

山城：ホスピタリストの歴史をみますと，内科系の G I Mから始まったホスピタリストと，カナダでは家 庭医からのホスピタリストが多いという報告があります。地域医療の崩壊が叫ばれる現在，学会としては 家庭医療専門医から病院総合医という基本コースを提案したのだと思います。ホスピタリストの議論をす るとかみ合わないことが多いので，まず基本コースを作ろうということになりました．

竹村：家庭医療学会としてクリニックの医師のみを育てるということは考えていません，今地域の住民が 最も必要としている医師を育てるために学会は研修プログラムを作りました。したがって，このプログラ ムで研修すれば地域でジェネラリストとして活躍するのに必要なものは全部含まれていると考えます。診 療所研修 6 ケ月だけでなく内科研修 6 ケ月も必修というのは病院総合医を強く意識して作りました。土台 として家庭医療専門医のプログラムはふさわしくないというご意見も聞かれますが，私としてはこのプロ グラムにはジェネラリストとして必要な研修は全部含まれていて，その上にさらに極めたい医師のために 病院総合医の研修があってもよいのでは，と思います。 
D：病院総合医は内科学会の総合内科専門医とどのように住み分けをするのでしょうか。両者の違いはど こにあるのでしょうか？

石丸：総合内科専門医の現在のプログラムは, 臨床面に関してはある程度整備されてはいるものの病院の 質改善や組織の中での総合性などの議論はほとんどないと思います。個人的には総合内科専門医のありか たも変わっていかなくてはならないと思います。

大滝: 関連して, 標榜科の問題, それから専門医制度認定機構への申請にも関連してくると思いますが伊 藤先生, いかがでしょうか?

伊藤：今後私ども学会に求められるのは，わかりやすさと同時にきちんと資格認定された家庭医を育てる ことだと思います。一方で, 厚生労働省のへき地医療対策協議会の検討会報告書が医政局指導課から出て います。その中で，へき地医療を担う医師像として，「総合的な診療能力を有し，プライマリ・ケアを実践 できるいわゆる総合医を育成していく必要がある。具体的にはへき地において, 初期救急, 二次救急の卜 リアージ, 病気の予防, 慢性疾患の管理, みとりなど総合的に行う医師が挙げられる. プライマリ・ケア 関連 3 学会が認定制度など作っていくのを今は見ていくべきである云々」という記載がされています。こ のようなメディアや検討会の方向をみてもわかるのですが, 地域のクリニック, 小病院で行われる医療を 支える人たちを支援し, 育てていくのが今後の日本プライマリ・ケア連合学会の最大の仕事であると思い ます。そこには総合内科専門医とは違う視点があるのではないかと思います。総合内科専門医 $+a$ の知識 と技術を提供することが日本プライマリ・ケア連合学会の仕事になると思います。専門医コースのBコー スは，研修施設をひとつに固定しないで，医師の診療経験に基づいて専門医への道を拓くような仕組みは 作っていくつもりですので，今後地域を支えていく医師を育て認定していく制度設計はできるのではない でしょうか.

$\mathbf{E}:$ 新学会で平成 22 年度の専門医試験が行われると思いますが, 私の理解では, 現時点では家庭医療学会 もしくはプライマリ・ケア学会のいずれかの専門医試験の受験資格を有した人が受験できて, C S A と M $\mathrm{E} \mathrm{Q}$ で行うということですね。病院総合医はその上に乗っていると理解しています，2つの学会の制度は いずれ，2 階建ての 1 階の部分，つまり家庭医療専門医の部分に一本化することを目指していくのかお聞 かせください.

伊藤: 2014 年までは, 現行のプライマリ・ケア学会と家庭医療学会の 2 つの制度のどちらかに乗っかってい ただいた方が，受験資格があるとご理解願います。そその後は一本化をしていきますが，今後 4 年間につい ては，現行の研修をされている方々に不利益にならないシステム作りはいたします。

$\mathbf{F}$ : 本日のフォーラムに参加して 3 学会がひとつになり全人的な医療をきちんと行う医師を育てたいとい う思いを聞いてうれしく思いました。総合内科専門医との違いは，総合医は病気の診断・治療が目的では なく生活, Q O Lを意識しながら診断・治療を考えるところに差があるのかなと思います，質問は，若い 学生に家庭医や総合医になりたいという人が少ない，基本的に高齢社会を迎えた国家の要請であり，基本 だと思います。この流れに入ってくるのが若い人たちのモラルになるのか，もうインセンテイブを高める にはどうすべきでしょうか？

大滝：いかがでしょうか？医学生がこの領域に入ってきやすくする誘導策は？

竹村 : 三重大学の入学試験で面接すると, 受験テクニックもあるのでしょうが 8 割くらいは総合医になり たいという印象です。しかし 6 年間過ぎるとなぜかその割合は減少してしまいます (笑)。でも極端に少な いのではなくそれなりの数はいます。重大学では 1 年生から地域医療に接する機会をできるだけ多くし て, 地域医療を充実させる必要性や地域で働くことの意義・生きがいを感じさせています。もっと強力な インセンティブはないのか，さらに考えています。

山城：WGではプログラムだけを作ってきたのですが，最近の事情を考えますと，日本プライマリ・ケア 


\section{日本総合診療医学会 国際フォーラム「あるべき病院総合医像を求めて」記録}

連合学会で 3 年間家庭医療専門医研修プログラムで研修し, そのあと 2 年間をかけて, 日本型ホスピタリ ストの専門医制度を構築すべきかなと個人的には思っています。専門医になると各施設で活躍できるとい う仕組みが必要ではないでしょうか？

大滝：予定の時間になりました，以上でシンポジウム 1 「認定制度はこう変わる一日本プライマリ・ケア

連合学会による認定医と専門医制度について」を終了します。 